УДК $81 ’ 37=811.111=811.112 .2=811.134 .2$

(C) О. С. Джеріх

(Вінниця)

\title{
СЕМАНТИКА ДІССЛІВ ПЕРЕСУВАННЯ У ВОДНОМУ СЕРЕДОВИЩІ В ГОРИЗОНТАЛЬНІЙ ПЛОЩИНІ (НА МАТЕРІАЛІ АНГЛІЙСЬКОЇ, НІМЕЦЬКОЇ ТА ІСПАНСЬКОЇ МОВ)
}

Стаття присвячена дослідженню семантичних особливостей дієслів пересування у водному середовищі в горизонтальній площині у різноструктурних мовах. В роботі розглядаються ізоморфні та аломорфні риси у семантичній структурі дієслів пересування, які були розділені на 3 лексико-семантичні групи. У статті описано основні теоретичні аспекти компонентного аналізу, за допомогою якого було проведено класифікацію зазначених дієслів. Звернено увагу на структурну організацію лексико-семантичної групи дієслів, до складу якої входять інтегральні та диференційні компоненти.

Ключові слова: дієслова переміщення, лексико-семантична група.

\section{Е.С.ДЖЕРИХ. СЕМАНТИКА ГЛАГОЛОВ ДВИЖЕНИЯ В ВОДНОМ} ПРОСТРАНСТВЕ В ГОРИЗОНТАЛЬНОЙ ПЛОСКОСТИ (НА МАТЕРИАЛЕ АНГЛИЙСКОГО, НЕМЕЦКОГО И ИСПАНСКОГО ЯЗЫКОВ)

Статья посвящена исследованию семантических особенностей глаголов движения в водной среде в горизонтальной плоскости в разноструктурных языках. В работе рассматриваются изоморфные и алломорфные черты в семантической структуре глаголов движения, которые были разделены на 3 лексико-семантические группы. В статье описаны основные теоретические аспекты компонентного анализа, с помощью которого была проведена классификация указанных глаголов. Уделяется внимание структурной организации лексикосемантической группы глаголов, в состав которой входят интегральные и дифференциальные компоненты.

Ключевые слова: глаголы движения, лексико-семантическая группа.

1. Постановка проблеми. Фундаментальною категорією людського буття $\epsilon$ простір, одна 3 найбільш спільних форм існування вічної матерії, при цьому рух визначається філософією як найважливіший атрибут цього простору (Чокубаєва, 2007).

Категорія простору, яка знаходить своє вираження в мові за допомогою різних частин мови, у тому числі дієслів, не співвідноситься безпосередньо ні з однією мовною категорією, але в той же час «пронизує» багатьох з них (Греймас, 2004). Поряд з часом, категорія простору входить до числа базових понять, за допомогою якого люди сприймають навколишній світ, та реалізується в кожній мові по-різному, оскільки кожна мова по-своєму членує позамовну дійсність та по-своєму відображає реальні зв’язки, що існують між різними предметами та явищами дійсності (Стернин, 1979).

У будь-якій мові слова існують не ізольовано, а вступають у різноманітні відношення з іншими словами, утворюючи певну систему. Слово підлягає аналізу як лексема в усіх своїх формах та лексичних значеннях. Об'єднання слів як одиниць словникового складу виконується завдяки основній для слова ознаки - лексичному 
значенню слова (Кодухов, 1974). У цьому випадку лінгвістичному аналізу підлягають не тільки семантичні зв'язки слів, як в синонімічних чи антонімічних рядах, а і його лексико-граматичні зв'язки, у формі яких реалізуються окремі значення слова. Внутрішньогрупові семантичні відмінності слів виражаються різними видами словесних зв'язків: формами одного й того ж слова, різноманітними словосполученнями у рамках синтагми та постійними протиставленнями у системі лексики в цілому (синонімічні, антонімічні ряди слів) (Чокубаева, 2007: 137).

Найбільш традиційною ланкою системної організації лексики є семантичні (або лексико-семантичні) групи, які об'єднують слова однієї частини мови і в яких, окрім диференційних семантичних компонентів, є щонайменше ще одна спільна інтегральна сема (Конобеева, 2004).

Наприклад, у слові англ. to wander 'пересуватися за допомогою ніг, не маючи певного напрямку чи мети’ граматична сема «дія предмета» уточнюється інтегральною семою 'пересуватися', а конкретизаторами служать диференційні семантичні компоненти ‘за допомогою ніг', ‘не маючи певного напрямку’, ‘без мети'.

Лексико-семантичні групи (ЛСГ) об'єднують слова однієї частини мови однакової предметної спрямованості, та в цьому відношенні вони зближаються з тематичними, термінологічними та синонімічними групами слів (Васильев, 1990). Під першою частиною визначення «лексико-семантична» мається на увазі, що такі групи об'єднують слова однієї частини мови, у яких, окрім спільних граматичних сем, наявна ще принаймні одна спільна сема - категоріально-лексична. Тобто одиниці мови у групі не тільки належать до однієї частини мови, але в їхньому значенні ще є спільний компонент (Кацнельсон, 2011: 178), який вважається крайнім компонентом у семантиці та $є$ дуже важливим для аналізу внутрішньої парадигми слова. М. Д. Степанова дає наступне визначення мінімальної семантичної одиниці: «сема - це найдрібніший елемент значення, який входить до складу інформації тієї чи іншої одиниці мови». (Степанова, 1978)

У представленій роботі було виділено дві інтегральні семи, а саме 'пересуватися у водному середовищі' та 'пересуватися у горизонтальній площині', оскільки ці семантичні компоненти наявні в кожній досліджуваній лексемі, напр.:

англ. to sail 'пересуватися, подорожувати на човні або кораблі';

нім. tellern 'пересуватися у воді на спині за допомогою гребків руками та відштовхування ногами'; 
icп. flotar 'триматися на поверхні води, не тонути'.

У наведених лексемах наявні семи 'пересуватися у воді' та 'пересуватися у горизонтальній площині', що їх об’єднують.

Окрім інтегральних сем, також виділяють диференційні компоненти. Слід відзначити, що при дослідженні дієслів пересування у воді важливу роль мають такі семантичні ознаки, як 'напрямок руху’ та 'ступінь активності руху’.

Переміщення у воді можна розглядати у горизонтальній та вертикальній площинах, причому у вертикальній площині суб'єкт може рухатися вгору або донизу. Дієслова зі значенням пересування в горизонтальній площині, які розглядаються в цій статті, можна поділити на три ЛСГ за семантичною ознакою 'ступінь активності руху': ЛСГ дієслів зі значенням активного, пасивного та опосередкованого пересування (Майсак, 2007).

Категорія пересування у просторі та іï відображення у мові привертає увагу як вітчизняних, так і зарубіжних лінгвістів. Дієслова руху вивчались у семантичному напрямку (Е. В. Рахіліна, В. А. Плугнян), розглядалась лексична сполучуваність цих дієслів (Т. А. Майсак), досліджувались не тільки первинні значення дієслів переміщення, а й переносні (А. Сленко, А. Голоднов). ЛСГ дієслів пересування у водному просторі розглядалась як складова частина ЛСГ «дієслова переміщення» за семантичною ознакою «середовище руху» (В. Г. Гак, Н. Б. Іваницька, Ч. Філмор, Л. Талмі).

Актуальність зумовлена підвищеним інтересом лінгвістів до дієслів переміщення у просторі. Незважаючи на всю різноманітність наукових робіт, присвячених цій тематиці, відсутній комплексний аналіз дієслів переміщення у воді у зіставному аспекті. Актуальність також полягає у необхідності грунтовного вивчення та виявлення ізоморфних та аломорфних рис у досліджуваних мовах.

Мета дослідження полягає у виявленні спільних та відмінних рис дієслів переміщення у водному середовищі в горизонтальній площині в англійській, німецькій та іспанській мовах.

Для досягнення поставленої мети необхідно вирішити наступні завдання:

1) виявити семантичні ознаки дієслів переміщення у водному середовищі як основу для їхньої семантичної класифікації;

2) провести аналіз структури значення дієслів переміщення у водному середовищі та виявити семантичні компоненти; 
3) провести семантичну класифікацію дієслів переміщення у водному середовищі на основі компонентного аналізу з кількісною характеристикою семантичних груп;

4) виявити спільні та відмінні риси в семантичній структурі дієслів переміщення у водному середовищі у досліджуваних мовах;

5) надати пояснення щодо відмінних рис 3 урахуванням лінгвістичних та позамовних факторів.

Об’сктом дослідження є дієслова переміщення у водному середовищі в горизонтальній площині в англійській, німецькій та іспанській мовах, а предметом дослідження $є$ семантичні характеристики дієслів переміщення у водному середовищі в горизонтальній площині.

Матеріал дослідження становлять дієслова, що позначають переміщення у водному просторі, в англійській, німецькій та іспанській мовах, отримані методом суцільної вибірки з тлумачних, двомовних та словників синонімів. Загальний обсяг вибірки становить 206 одиниць (в англійській - 71, в німецькій - 72, в іспанській - 63).

Наукова новизна роботи полягає в тому, що вперше проведено комплексну класифікацію дієслів пересування у водному просторі в англійській, німецькій та іспанській мовах. Запропонована модель системного опису зазначених дієслів, що забезпечує можливість зіставного вивчення дієслів зі значенням переміщення у воді в досліджуваних мовах.

Отримані результати мають теоретичну цінність для подальших наукових досліджень у сфері лексичної семантики дієслів руху. Практична цінність полягає у використанні результатів проведеного дослідження у навчальному процесі (порівняльна лексикологія, загальне мовознавство).

2. Аналіз практичного матеріалу. У представленій роботі розглядаються дієслова зі значенням пересування у воді, які характеризуються різним ступенем активності. Протиставлення між ситуаціями, які можна умовно поділити на активне та пасивне плавання, є важливим фактором під час дослідження зазначених дієслів в семантичному аспекті. Суб’єкт активного плавання самостійно, активно рухається у воді за допомогою рухів ніг, рук, спини (про людину), плавників, хвоста (про риб) тощо. Суб'єкт пасивного плавання не може пересуватися самостійно. Пасивне плавання пов'язане з переміщенням за допомогою природних факторів, каузативних відношень або більш-менш нерухомим станом суб'єкта на поверхні або в товщі води. Поряд 3 активним та пасивним плаванням слід виділити опосередковане пересування, до якого 
можна віднести рух водних транспортних засобів та рух за допомогою цих засобів та яке має ознаки активного та пасивного переміщення. Аналіз вказаних семантичних ознак дозволив виділити описані нижче лексико-семантичні групи.

\section{1 Дісслова пересування у водному середовищі зі значенням активного} переміщення у горизонтальній площині

До ЛСГ дієслів активного плавання у горизонтальній площині (див. табл. 1), яка включає 76 лексем (англ. - 21, нім. - 32, ісп. - 23) належать дієслова, які описують самостійне переміщення у водному просторі, напр.:

англ. to butterfly 'плавати на животі, роблячи симетричні гребки руками над головою, причому тіло рухається хвилеподібно';

нім. fortschwimmen 'рухатися вперед у воді';

iсп. nadar 'пересуватися у воді, рухаючись кінцівками (про людину або тварину).

До зони активного плавання можна віднести також дієслова, що позначають різні стилі плавання. Якщо для німецької мови характерними є дієслова на позначення стилів плавання, утворені за допомогою складання основ, то для англійської та іспанської мов більш звичайно передавати значення цих лексем за допомогою не однослівних засобів, що, насамперед, пов'язано з тим, що німецьку відносять до синтетичних мов, а іспанську та англійську - до аналітичних (Talmy, 2003), напр.:

англ. to swim the crawl 'плавати кролем', to do / to swim the backstroke 'плавати на спині'

нім. brustschwimmen ‘плавати брасом’ (die Brust 'груди’ + schwimmen 'плавати’)

ісп. nadar a crawl 'плавати кролем', nadar a braza 'плавати брасом'

Цілеспрямованість руху в німецькій мові зазвичай визначається за допомогою префіксів. В німецькій мові можна виділити семантичну ознаку 'напрямок руху в горизонтальній площині', який конкретизується в диференційних семах, таких як ‘наближення до якого-небудь суб’єкта' та ‘віддалення'. Дериваційна продуктивність німецьких дієслів пересування проявляється у здатності приєднувати до твірних основ словотвірні префікси (an-, heran-, weg-, hin-, zu-), напр.: нім. schwimmen 'плисти' anschwimmen 'наближатися, пливучи по воді'.

Pfeil schnell schwamm der Наі an. 'Акула приплила швидко, немов стріла'.

Отже, завдяки префіксу an- семантична структура дієслова нім. schwimmen ‘пересуватися по воді за допомогою рук та ніг’ збагачується семантичним компонентом 'наближатися до чого-небудь'. 
На відміну від німецької мови, де семантичний компонент 'цілеспрямованість руху' передається за допомогою словотвірних префіксів, в іспанській мові морфологічний спосіб утворення слів $\epsilon$ менш продуктивним. Тому для надання інформації про конкретний напрямок руху плавця зазвичай використовуються двопредикатні конструкції, які складаються з загального дієслова руху, який вказує на напрямок пересування відносно мовця, та дієслова плавання. В англійській мові, в якій дієслова можуть поєднуватися з прийменниками, набуваючи додаткових значень та утворюючи єдину семантичну та синтаксичну одиницю, для передачі семи цілеспрямованості руху застосовуються фразові дієслова, напр.:

англ. to swim away 'відпливати'

icп. venir nadando ‘припливати’ (досл. ‘наближатися, пливучи’);

iсп. irse nadando ‘відпливати’ (досл. 'віддалятися, пливучи').

\section{2 Дісслова пересування у водному середовищі зі значенням пасивного} переміщення у горизонтальній площині

Суб'єкти пасивного плавання не докладають ніяких зусиль для пересування. Тіло переміщається за допомогою течії, під дією сили вітру, земного тяжіння та інших природних факторів, які обумовлюють пересування у воді. Пасивне плавання також передбачає більш-менш нерухоме знаходження на поверхні або у товщі води.

ЛСГ дієслів пасивного пересування у воді в горизонтальній площині (див. табл. 1) представлена 11 одиницями в англійській мові, 10 - в німецькій, 13 - в іспанській. Досить низька продуктивність дієслів з цим значенням пояснюється тим, що живим істотам більш властиво пересуватися самостійно, а не під дією природних явищ. Пересування кораблів, човнів та інших видів водного транспорту, якщо ним керує людина, також не можна віднести до пасивного плавання - лише некеровані предмети завжди пересуваються під дією яких-небудь факторів.

До групи пасивного плавання можна віднести такі дієслова:

англ. to drift 'переміщатися на поверхні води під силою потоку повітря чи води', нім. treiben ‘пасивно переміщатися у воді під силою природних факторів', iсп. flotar 'триматися на поверхні рідини, не тонути'.

В англійській мові для позначення пасивного плавання, окрім to drift також вживається дієслово англ. to float. Обидва можуть описувати пересування як у водному, так і у повітряному середовищах. Однак у семантичній структурі цих лексем є значні відмінності. По-перше, лексема англ. to float, як ісп. sobrenadar, може вживатися 
тільки, якщо йдеться про пасивне плавання на поверхні води, тоді як англ. to drift також описує пересування у товщі води. По-друге, to float описує лише рух легких, невеликих предметів, які не занурюються у воду. Отже, чим важчий предмет та чим більше він занурюється у товщу води, тим менша вірогідність того, що у цьому випадку буде застосовуватися англ. to float. По-третє, англ. to drift завжди вказує на стихійну ситуацію, коли суб’єкт не може контролювати свої рухи, його несуть хвилі, сильний вітер або течія. Натомість, to float ніякої напруги чи стихійної ситуації не передбачає. На рухи суб'єктів to float хоча й впливає середовище, але вони зберігають внутрішній спокій та рівновагу, вони немовби відпочивають (у випадку живих істот), повільно пересуваючись на поверхні води. На відміну від to drift, to float передбачає те, що тіло не тоне, а лише перебуває на поверхні у нерухомому стані.

Якщо англ. to float та icп. flotar описують лише знаходження та незначне переміщення легких предметів на поверхні води, нім. treiben тлумачать як пасивне переміщення, викликане зовнішнім середовищем. Тому суб'єктами нім. treiben можуть також виступати човни, кораблі та інші водні транспортні засоби.

В іспанській мові найбільш поширеним дієсловом пасивного нецілеспрямованого плавання $\epsilon$ icп. flotar. Слід зауважити, що в той час як англ. to float означає тільки переміщення на поверхні води, суб'єкт ісп. flotar може буде як зануреним у товщу води, так і пасивно пересуватися на поверхні.

\section{3 Дісслова пересування $\quad$ у водному середовищі $\quad$ зі значенням} опосередкованого переміщення у горизонтальній площині

До складу ЛСГ опосередкованого руху (див. табл. 1) відносять дієслова зі значенням плавання суден та за допомогою суден, що не можна віднести ні до групи активного плавання, ні до групи пасивного плавання (англ. - 39 одиниць, нім. - 30, ісп. - 28). 3 одного боку, судно пересувається самостійно та має конкретний напрямок. 3 іншого боку, пересування будь-якого судна контролюється людиною, використовується сила вітру або течії для переміщення у воді.

В англійській мові кількість дієслів, що мають семантичний компонент ‘опосередковане пересування' більше, ніж в німецькій та іспанській, що було обумовлено як лінгвістичними (конверсія), так і позамовними (Британія - це острівна країна, економіка якої з давніх-давен пов'язана з мореплавством) факторами;

Широко розвинене мореплавство та суднобудування не тільки відіграло велику роль в історії Англії та Іспанії, а й вплинуло на лексичний склад мови у цій сфері. Ще у 
бронзову добу мешканці Іспанії досягли високого рівня цивілізації, яка була основана на металургії, мореплавстві та торгівлі з іншими народами, а наприкінці XVI століття було зібрано великий військово-морський флот, який здобув назву - Непереможна Армада, для розгрому англійського флоту під час англо-іспанської війни.

Серед дієслів, які описують плавання за допомогою водних транспортних засобів, можна віднести такі лексеми:

англ. to sail 'пересуватися, мандрувати на човні або кораблі', to navigate 'спрямовувати рух судна',

ісп. navegar 'пересуватися на судні по воді або на літаку у повітрі', marear 'приводити в рух судно та керувати ним', bogar 'пересуватися на судні, гребучи веслами',

нім. rudern 'занурювати весло у воду, проштовхувати його крізь воду та знову підіймати на поверхню’.

На відміну від англ. to sail, суб’єктами нім. segeln можуть бути лише вітрильні судна. Коли суб’єктом виступають невітрильні судна, такі як пароплав, пліт або катер, то зазвичай використовуються дієслова пересування наземних транспортних засобів, до яких можна віднести нім. fahren 'пересуватися вперед на транспортному засобі'.

В іспанській мові, на відміну від англійської (to sail), немає дієслова для позначення пересування судна за допомогою вітрил. Тому для передачі даного значення використовується вираз ісп. navegar a la vela 'плисти під вітрилами'.

Особливістю англійської мови $\epsilon$ конверсія, за допомогою якої в семантичній групі дієслів зі значенням опосередкованого плавання наявний цілий ряд дієслів, які $є$ похідними від весел різного типу або засобів водного транспорту на відміну від іспанської мови, для словотвору якої не характерне застосування конверсії, в результаті чого виникає доволі широка, порівняно 3 англійською мовою, лакунарна зона, обумовлена, в першу чергу, внутрішньосистемними факторами. Денотативне значення зазначених англійських дієслів досить вузьке, оскільки воно передає специфічний спосіб пересування, який можна співвіднести 3 параметрами функціонування відповідних пристроїв. В німецькій мові також були виявлені дієслова, утворені від назв весел, за допомогою яких тіло пересувається по воді, напр.:

англ. a paddle ‘байдаркове весло’ - to paddle 'гребти байдарковими веслами', a scull ‘коротке кормове парне весло' - to scull 'грести парними веслами', an oar 'весло' to oar 'гребти, іти на веслах', 
нім. rudern 'занурювати весло у воду, проштовхувати його крізь воду та знову підіймати на поверхню' - das Ruder 'весло', skullen 'гребти парними веслами' - das Skull 'парне, кормове весло', paddeln 'проштовхувати вперед човен за допомогою байдаркових весел’ - das Paddel ‘байдаркове весло’,

iсп. ir a batea 'плавати на плоскодонці', remar con canalete 'гребти байдарковими, широкими веслами', ir en сапое ‘пересуватися на каное'.

Таблиия 1

\section{Лексико-семантичні групи дісслів пересування у водному просторі}

в горизонтальній площині в англійські, німецькій та іспанській мовах та їхня кількісна характеристика

\begin{tabular}{|c|c|c|c|c|c|c|}
\hline & \multicolumn{2}{|c|}{ Англійська } & \multicolumn{2}{|c|}{ Німецька } & \multicolumn{2}{|c|}{ Іспанська } \\
\hline ЛСГ & К-сть & Приклад & К-сть & Приклад & К-сть & Приклад \\
\hline $\begin{array}{l}\text { Активне } \\
\text { пересування }\end{array}$ & $\begin{array}{c}21 \\
(30 \%)\end{array}$ & $\begin{array}{l}\text { to backstroke } \\
\text { 'плавати на } \\
\text { спині' }\end{array}$ & $\begin{array}{c}32 \\
(44 \%)\end{array}$ & $\begin{array}{l}\text { fortschwimme } \\
\text { ' 'плисти } \\
\text { вперед' }\end{array}$ & $\begin{array}{c}23 \\
(36 \%)\end{array}$ & $\begin{array}{l}\text { nadar } \\
\text { 'плавати' }\end{array}$ \\
\hline $\begin{array}{l}\text { Пасивне } \\
\text { пересування }\end{array}$ & $\begin{array}{c}11 \\
(15 \%)\end{array}$ & $\begin{array}{l}\text { to float } \\
\text { 'триматися } \\
\text { на поверхні } \\
\text { води' }\end{array}$ & $\begin{array}{c}10 \\
(14 \%)\end{array}$ & $\begin{array}{l}\text { driften } \\
\text { 'дрейфувати' }\end{array}$ & $\begin{array}{c}13 \\
(20 \%)\end{array}$ & $\begin{array}{l}\text { flotar } \\
\text { ‘триматися } \\
\text { на } \\
\text { поверхні } \\
\text { води’ }\end{array}$ \\
\hline $\begin{array}{l}\text { Опосередковане } \\
\text { пересування }\end{array}$ & $\begin{array}{c}39 \\
(55 \%)\end{array}$ & $\begin{array}{l}\text { to paddle } \\
\text { 'гребти } \\
\text { байдаркови } \\
\text { ми веслами' }\end{array}$ & $\begin{array}{c}30 \\
(42 \%)\end{array}$ & $\begin{array}{l}\text { rudern } \\
\text { 'веслувати' }\end{array}$ & $\begin{array}{c}28 \\
(44 \%)\end{array}$ & $\begin{array}{l}\text { bogar } \\
\text { 'веслувати' }\end{array}$ \\
\hline Усього & $\begin{array}{c}71 \\
(100 \%)\end{array}$ & & $\begin{array}{c}72 \\
(100 \%)\end{array}$ & & $\begin{array}{c}63 \\
(100 \%)\end{array}$ & \\
\hline
\end{tabular}

3. Висновки. На основі представленого у роботі матеріалу можна зробити такі висновки: дослідження дієслів переміщення у воді за ступенем активності базується на протиставленні ситуацій, які можна умовно поділити на активне, пасивне та опосередковане пересування у воді.

В англійській мові кількість дієслів, що мають семантичний компонент ‘опосередковане пересування’ більше, ніж в німецькій та іспанській, що було обумовлено як лінгвістичними (конверсія), так і позамовними (Британія - це острівна країна, економіка якої з давніх-давен пов’язана з мореплавством) факторами;

В іспанській та англійській мовах, на відміну від німецької, значення дієслів, що описують різноманітні стилі плавання, передаються переважно за допомогою неоднослівних засобів; це, насамперед, пов’язано з тим, що німецьку відносять до синтетичних мов, а іспанську та англійську - до аналітичних. 
Найменш продуктивною групою в досліджуваних мовах виявилась група дієслів, що позначають пасивне пересування у воді. Досить низька продуктивність дієслів 3 цим значенням пояснюється тим, що живим істотам більш властиво пересуватися самостійно, а не під дією природних явищ. Пересування кораблів, човнів та іншого водного транспорту, якщо ним керує людина, також не можна віднести до пасивного плавання. Лише некеровані предмети завжди пересуваються під дією яких-небудь факторів.

\section{СПИСОК ЛІТЕРАТУРИ}

1. Васильев Л.М. Современная лингвистическая семантика / Л.М. Васильев. - М.: Высшая школа, 1990. - $175 \mathrm{c}$.

2. Греймас А-Ж. Структурная семантика. Поиск метода / А-Ж. Греймас. - М.: Академический проект, 2004. - 368 с.

3. Іваницька Н.Б. Дієслівне вираження мікрокатегорії «рух» в українській та англійській мовах / Н.Б. Іваницька // Наук. вісник Чернівецького ун-ту. Серія «Філологічні науки». - Вип. 86. - Чернівці, ЧНУ, 2010. - С. 97 - 105.

4. Кацнельсон С.Д. Содержание слова, значения и обозначение / Под общ. ред. В.М. Жирмунского, М.М. Гухмая, С.Д. Кацнельсона. Изд. 3-е. М.: Едиториал УРСС, 2011. $112 \mathrm{c}$.

5. Кодухов В.И. Общее языкознание / В.И. Кодухов. - М.: Высшая школа, 1974. - 303 с.

6. Конобеева А.О. Глаголы движения с локальними префиксами в категоризации пространственных отношений в современном немецком языке: автореф. ... канд. филол. наук. : 10.02.04 / А.О. Конобеева. - Тамбов, 2006. - 19 с.

7. Корунець Ш.В. Порівняна типологія англійської та української мов: Навчальний посібник. - К.: Либідь, 1995.

8. Майсак T.A., Рахилина Е.В. Глаголы движения в воде: лексическая типология. - М.: Индрик, 2007. - 752 с.

9. Степанова Г.В. Семантика многозначного слова: Учеб. пособ.- Калининград, 1978.$50 \mathrm{c.}$

10. Стернин И.А. Проблемы анализа структуры значения слова / И. А. Стернин. Воронеж: Изд-во Воронежск. ун-та, 1979. - 156 с.

11. Чокубаева А.К. Лексико-семантический анализ глаголов в английском языке и их сопоставление с русским и кыргызским языками: дис. ...канд. филол. наук: 10.02.20 / А.К. Чокубаева. - Бишкек, 2007. - 22 с.

12. Talmy L. Toward a Cognitive Semantics. Vol. 2 / L. Talmy. - Cambridge, MA: MIT Press 2003. -503 p. 